УДК 343.163

DOI https://doi.org/10.32849/2663-5313/2020.2.54

Ірина Курбатова,

канд. юрид. наук,

стариий прокурор прокуратури м. Києва

\title{
УЧАСТЬ ПРОКУРОРА У ПЕРЕГЛЯДІ СУ ДОВИХ РІШЕНЬ СУДОМ АПЕЛЯЦІЙНОЇ ІНСТАНЦІї
}

У статті здійснено теоретичний та нормативно-правовий аналіз участі прокурора у перегляді кримінальних справ судом апелячійної інстанцї. Основна мета роботи полягає у дослідженні проблемних питань, пов'язаних з участю прокурора в перегляді судових рішень у кримінальних провадженнях, формуванні та науковому обгрунтуванні висновків $і$ пропозицій, спрямованих на вдосконалення проиедури участі прокурора у стадї перегляду судових рішень.

Встановлено, що можливість перевірки законності, обгрунтованості та вмотивованості судових рішень в апелячійному провадженні за апелячійною скаргою зачікавлених осіб вважається конституиійною гарантією правосуддя, що забезпечує право особи оскаржити судове рішення шляхом внесення апеляції учасниками судового процесу. Серед таких учасників особливе місце посідає прокурор.

Констатовано, що стадія апелячійного провадження є гарантією забезпечення постановлення законного, обгрунтованого та справедливого судового рішення. Водночас перегляд судових рішень апеляційно інстанцією передбачає формування єдиного підходу до застосування кримінального та кримінального процесуального законодавства України, що закріплює низку важливих положень, які регламентують повноваження прокурора саме на иій стадії кримінального судочинства.

Доведено, що у разі порушення норм матеріального чи процесуального права прокурор зобов'язаний своєчасно реагувати на незаконні судові рішення шляхом внесення апеляиї з метою виконання покладеної на нього законом правозахисної функиії, зміст якої полягає у захисті й відновленні порушених прав громадянина та людини, інтересів держави і суспільства. Механізм реалізаиї иієі функиії полягає в тому, що прокурор протягом строків, відведених на оскарження судових рішень, які не набрали законної сили, має ознайомитись із ними та матеріалами судового розгляду, апеляціями інших учасників прочесу, подати письмові заперечення щодо них, своєчасно внести апелячію на кожне незаконне судове рішення та взяти участь у розгляді кримінальної справи в апеляційному суді.

Значна увага приділена нормативно-правовому регулюванню участі прокурора у суді апелячійної інстаниї, унормуванню порядку подачі апелящійної скарги прокурорами різного рівня, а також відомчому контролю за процесом оскарження незаконних судових рішень. Підкреслено, що в окремих кримінальних провадженнях лише прокурор як державний обвинувач може подати апеляційну скаргу на невмотивоване рішення суду першої інстаниї у зв'язку з тим, що потерпілого у таких справах немає, а сторона захисту не зачікавлена у перегляді такого судового рішення.

Ключові слова: прокурор, рішення суду, апеляційна скарга, апеляційне провадження, Генеральний прокурор.

Постановка проблеми. Чинний Кримінальний процесуальний кодекс України (далі - КПК України) вніс кардинальні зміни до розуміння ролі та завдань органів прокуратури як учасника процесу доказування у кримінальному провадженні. У зв'язку з цим визначення процесуального становища прокурора як суб'єкта доказування в кримінальному судочинстві є, вочевидь, найбільш актуальним питанням сучасної доктрини доказового права. Особливо це питання актуалізується у разі визначення ролі прокурора у стадії кримінального процесу під час перегляду судових рішень.

Законне та справедливе вирішення кримінально-правового конфлікту ста- вить перед юридичною наукою завдання щодо зменшення кількості помилок під час досудового провадження та судового розгляду матеріалів кримінальних проваджень, а також пошуку шляхів їх виправлення. На практиці іноді трапляються випадки, коли судові рішення ухвалюються 3 порушенням матеріального або процесуального закону.

Найпоширенішим у сучасному кримінальному судочинстві способом виправлення таких помилок $є$ оскарження будьякого судового рішення, що не набрало чинності, в суді вищої інстанції - апеляційному суді. Саме суд апеляційної інстанції має забезпечити постановлення законних, обгрунтованих та вмотивованих судових 
рішень, а також вжиття своєчасних заходів, спрямованих на виправлення помилок, допущених на попередніх стадіях кримінального судочинства.

Відповідно до п. 8 ст. 129 Конституції України [1] однією із фундаментальних засад судочинства $є$ право на апеляційне та касаційне оскарження судових рішень, окрім випадків, встановлених законом. Аналогічні норми містяться також у ст. 14 Закону України «Про судоустрій та статус суддів», процесуальних кодексах України. Поряд із національним законодавством це право проголошено і у міжнародних актах, зокрема: відповідно до п. 5 ст. 14 Міжнародного пакту про громадянські і політичні права 1966 р. кожен, кого засуджено за будь-який злочин, має право на те, щоб його засудження і вирок були переглянуті вищестоящою судовою інстанцією згідно із законом та ч. 2 ст. 2 Протоколу № 7 до Конвенції про захист прав людини та основоположних свобод, кожен, кого суд визнав винним у вчиненні кримінального правопорушення, має право на перегляд вищою судовою інстанцією винесеного йому вироку або призначеної міри покарання

Отже, можливість перевірки законності, обгрунтованості та вмотивованості судових рішень в апеляційному провадженні за апеляційною скаргою зацікавлених осіб вважається конституційною гарантією правосуддя, що забезпечує право особи оскаржити судове рішення шляхом внесення апеляції учасниками судового процесу. Серед таких учасників особливе місце посідає прокурор.

Аналіз останніх досліджень. Проблеми законодавчого регулювання участі прокурора на стадії перегляду судових рішень досліджували у своїх працях В. Бесчасний, Л. Богословська, Т. Варфаломеєва, Ю. Грошевий, П. Каркач, О. Костюченко, С. Коваленко, М. Косюта, Л. Лобойко, В. Маляренко, О. Михайленко, М. Михеєнко, В. Шибіко та інші, праці яких мають суттєве наукове й практичне значення і $€$ підгрунтям подальших наукових досліджень.

Цілями статті $є$ дослідження основних проблемних питань, пов'язаних з участю прокурора в перегляді судових рішень у кримінальних справах, формування та наукове обгрунтування висновків і пропозицій, спрямованих на вдосконалення процедури участі прокурора у стадії перегляду судових рішень.

Виклад основного матеріалу. Особливе становище прокурора у цій стадії зумовлене тим, що провадження справ у апеляційній інстанції може виникнути тільки за наявності апеляційної скарги, а оскарження в касацій- ному порядку можливе лише тільки після апеляційного перегляду, подача прокурором апеляції має досить вагоме, а іноді вирішальне значення, адже засуджений чи його захисник і навіть інші суб'єкти апеляційного оскарження, передбачені ст. 393 КПК України [2], не завжди зацікавлені в оскарженні вироку або ухвали суду.

Так, без апеляції на безпідставне виправдання особи, незаконне звільнення особи від відбування призначеного покарання з випробуванням, м'якість призначеного покарання, безпідставне закриття провадження чи необхідності застосування норми закону про більш тяжкий злочин апеляційна та касаційна інстанції не можуть переглянути незаконне судове рішення. У подібних випадках сторона захисту не зацікавлена у перегляді судового рішення, а тому роль прокурора за таких умов має надзвичайно велике значення. Водночас $€$ кримінальні провадження, у яких немає потерпілих та інших зацікавлених осіб, як наприклад, злочини проти основ національної безпеки України (розділ I Особливої частини КК України), злочини проти довкілля (розділ VIII) та інші. На незаконність, необгрунтованість, невмотивованість чи несправедливість судових рішень у таких справах, крім прокурора, майже ніхто не реагує.

Стадія апеляційного провадження є гарантією забезпечення постановлення законного, обгрунтованого та справедливого судового рішення. Водночас перегляд судових рішень апеляційною інстанцією передбачає формування єдиного підходу до застосування кримінального та кримінального процесуального законодавства України, що закріплює низку важливих положень, які регламентують повноваження прокурора саме на цій стадії кримінального судочинства.

Відповідно до ч. 4 ст. 36 КПК України та ч. 5 ст. 24 Закону України «Про прокуратуру» [3] правом внесення апеляційної (касаційної) скарги на судові рішення у кримінальних справах наділені службові особи органів прокуратури, які брали участь у судовому розгляді як прокурори, а також незалежно від їхньої участі в розгляді справи прокурори вищого рівня - Генеральний прокурор та його заступники, керівники обласних прокуратур і прирівняні до них та їх заступники, крім випадків, коли йдеться про рішення у кримінальних провадженнях, розслідування в яких здійснювалося Національним антикорупційним бюро України, - у таких випадках відповідне право надається прокурору, який брав участь у судовому розгляді, а також незалежно від його участі в розгляді справи - керівнику Спеціалізованої антикорупційної прокуратури, його заступни- 
кам. Водночас статтями 393, 425 та 446 КПК України визначено коло осіб, які мають право подати апеляційну, касаційну та скаргу до Верховного Суду України, однак, ці статті містять лише згадку про прокурора як про суб'єкта апеляційного чи касаційного оскарження, не уточнюючи при цьому, який саме прокурор має право на подання апеляційної чи касаційної скарги. Разом із тим змінити, доповнити, відкликати, відмовитися від апеляційної, касаційної скарги, заяви про перегляд судового рішення Верховним Судом України має право прокурор, який її подав, або прокурор вищого рівня.

Отже, в разі порушення норм матеріального чи процесуального права прокурор зобов'язаний своєчасно реагувати на незаконні судові рішення шляхом внесення апеляції з метою виконання покладеної на нього законом правозахисної функції, зміст якої полягає у захисті й відновленні порушених прав громадянина та людини, інтересів держави і суспільства. Механізм реалізації цієї функції полягає в тому, що прокурор протягом строків, відведених на оскарження судових рішень, які не набрали законної сили, має ознайомитись із ними та матеріалами судового розгляду, апеляціями інших учасників процесу, подати письмові заперечення щодо них, своєчасно внести апеляцію на кожне незаконне судове рішення та взяти участь у розгляді кримінальної справи в апеляційному суді. Крім того, має право вносити зміни, доповнювати і навіть відкликати апеляційну скаргу.

Однак у юридичній літературі висловлюється думка, що відкликання апеляції вищестоящим прокурором поставить прокурора, який подав апеляцію, в нерівне становище 3 іншими учасниками судового розгляду справи. Таку ж думку висловили В. Маляренко та I. Вернидубов, які зазначають, що право на відкликання апеляції мусить мати лише той прокурор, який брав участь як державний обвинувач у розгляді справи судом першої інстанції та подав апеляційну скаргу [4, c. 208]. Зрозуміло, це положення не стосується апеляційної скарги, поданої вищестоящим прокурором.

Звертає на себе увагу й інша думка: правом на внесення змін і доповнень до апеляції прокурора може бути наділений вищестоящий прокурор, але в межах позиції, зазначеної в апеляції. Вказане необхідно закріпити у відповідних положеннях процесуального законодавства. Право на відкликання апеляції має залишитися лише за тією особою, яка іiї внесла. В іншому разі це може призвести до зловживань службовим становищем з боку вищестоящих прокурорів.
Водночас в апеляційному провадженні $\epsilon$ засада неможливості погіршення правового становища обвинуваченого, тобто не допускається подання таких апеляційних скарг, задоволення яких призведе до погіршення правового становища цього учасника кримінального процесу. Однак, на думку B.I. Маринів, винятки із зазначеного вище правила зводяться до виконання умови, що апеляція подається чітко визначеним суб'єктом - прокурором, потерпілим або його представником [5, с. 116].

Зокрема, відповідно до ст. 421 КПК України виключно прокурор, потерпілий та його представник мають право подавати апеляційні скарги з такими вимогами: 1) скасувати обвинувальний вирок у зв'язку з необхідністю застосувати закон про більш тяжке кримінальне правопорушення чи суворіше покарання, скасувати неправильне звільнення обвинуваченого від відбування покарання, збільшити суми, які підлягають стягненню, або в інших випадках, коли це погіршує становище обвинуваченого; 2) скасувати виправдувальний вирок (змінити такий вирок можна лише, коли змінюються мотиви виправдання, а резолютивна частина залишається); 3) скасувати ухвалу про застосування примусових заходів медичного чи виховного характеру у зв'язку з необхідністю застосувати закон про більш тяжке діяння або суворіший вид примусових заходів медичного чи виховного характеру; 4) скасувати ухвалу про відмову у застосуванні примусових заходів медичного чи виховного характеру та закриття кримінального провадження щодо неосудного або неповнолітнього, винесену з мотивів, що не вчинили кримінально караного діяння.

Аналіз ч. 1 ст. 420 КПК України щодо підстав для скасування вироку судом апеляційної інстанції та ухвалення свого вироку дає змогу дійти висновку про те, що прокурор є одним 3 небагатьох (поряд 3 потерпілим та його представником) суб'єктів, а у провадженнях, в яких відсутній потерпілий, єдиним суб'єктом, якому дозволено в апеляційній скарзі вимагати скасування вироку. Водночас норми КПК України та Закону України «Про прокуратуру» не містять жодних обмежень щодо права прокурора подавати апеляційну скаргу, задоволення якої може покращити правове становище обвинуваченого. Виняток встановлено лише статтею 394 КПК України, яка встановлюе обмеження щодо апеляційного оскарження окремих судових рішень (вироків, ухвалених у порядку спрощеного провадження; оскарження ніким не оспорюваних у суді першої інстанції обставин і дослідження яких було 
визнано судом недоцільним; вироків, ухвалених на підставі угод). Однак вирок, ухвалений на підставі угоди про визнання винуватості, може бути оскаржений прокурором виключно з підстав призначення судом покарання, менш суворого, ніж узгоджене сторонами угоди, а також затвердження судом угоди, яка не могла бути укладена [2].

Разом із тим прокурор здебільшого не є самостійним у прийнятті рішень, а діє за погодженням 3 керівником органу прокуратури або вищестоящими прокурорами, подання апеляційної скарги також вимагає дотримання певних адміністративних процедур, які не передбачені КПК України, однак унормовані відомчим Порядком організації діяльності прокурорів і слідчих органів прокуратури у кримінальному провадженні (далі - Порядок), затвердженим наказом ГПУ від 28.03.2019 р. № 51 [6].

Згаданий вище Порядок вимагає від прокурора у провадженні (старшого групи прокурорів), прокурора, який брав участь у суді апеляційної інстанції, під час перегляду судового рішення упродовж п’яти діб після ухвалення судом рішення скласти висновок $з$ правовою позицією щодо його законності і наявності підстав для подальшого оскарження цього рішення в апеляційному чи касаційному порядку, який упродовж трьох діб погоджується керівником відповідного структурного підрозділу та керівником прокуратури відповідного рівня, його першим заступником або заступником згідно з розподілом обов'язків. Керівники прокуратур обласного рівня, окружних прокуратур та військових прокуратур гарнізонів, їх перші заступники та заступники надсилають до уповноважених структурних підрозділів прокуратури вищого рівня висновок із правовою позицією щодо законності ухваленого судом першої або апеляційної інстанції рішення i наявності підстав для його перегляду - не пізніше наступної доби після його погодження.

Крім того, відповідно до ст. 36 КПК України та п. 15 Порядку структурні підрозділи нагляду за додержанням законів під час проведення досудового розслідування прокуратур обласного рівня забезпечують перевірку висновків окружних прокуратур про законність ухвалених судами першої інстанції рішень та відсутність підстав для їх оскарження в апеляційному порядку.

У разі встановлення підрозділами підтримання обвинувачення в суді обласних прокуратур та Офісу Генерального прокурора України підстав для подання апеляційної чи касаційної скарги, заяви про перегляд судового рішення за нововиявленими або виключними обставинами, доповнення, зміни або відмови від скарги, заяви, внесених ними або прокурорами нижчого рівня, вони письмово повідомляють про це заступника керівника обласної прокуратури, відповідального за стан організації наглядової роботи згідно з розподілом обов'язків [6].

Водночас може виникнути різна позиція прокурорів щодо оскарження судових рішень, у такому разі питання вирішується на відповідному рівні керівником обласної прокуратури чи Генеральним прокурором.

Під час підготовки апеляційної скарги прокурор мусить урахувати те, що апеляційний суд перевіряє законність рішення суду першої інстанції тільки щодо оскарженої частини рішення, і навпаки, не має перевіряти ті висновки суду, які не були предметом оскарження. У разі оскарження вироку суду першої інстанції прокурору необхідно звернути особливу увагу на вимоги ст. 420 КПК України щодо можливості скасування вироку суду першої інстанції і постановлення апеляційним судом свого вироку. Водночас згідно з вимогами ст. 404 КПК України суд апеляційної інстанції не має права розглядати обвинувачення, що не було висунуте в суді першої інстанції. Ця та інші норми сприяють економії часу і грошових ресурсів під час вирішення кримінальних справ, адже в такому разі справи не повертаються на новий судовий розгляд у повному обсязі. Разом із тим прокурору необхідно врахувати, що апеляційний суд не має права постановити свій вирок, якщо в апеляційній скарзі прокурора не ставилось питання про скасування вироку суду першої інстанції та постановлення нового вироку, подання апеляції саме 3 такими вимогами є досить важливим і відповідальним завданням прокурора. Якщо прокурор дійде висновку про необхідність скасування вироку суду першої інстанції і постановлення апеляційним судом свого вироку стосовно одного засудженого, а щодо інших засуджених - про необхідність зміни вироку, все це викладається в одній апеляційній скарзі. Задовольняючи таку апеляційну скаргу прокурора, апеляційний суд відповідно до ст. 418 КПК України скасовує повністю чи частково вирок суду першої інстанції і постановляє свій вирок щодо одного засудженого, а щодо зміни вироку стосовно інших засуджених - ухвалу.

Крім вироків, прокурор також може ставити в апеляційній скарзі питання про скасування ували місцевого суду щодо застосування до обвинуваченого примусових заходів виховного чи медичного характеру і постановлення апеляційним судом своєї ухвали. Прокурор в апеляційній скарзі мусить посилатись тільки на ті докази і обставини, які 
підтверджують апеляційні вимоги, виділяти головне й уникати зайвої інформації, що не має суттєвого значення для вирішення справи. Не можна посилатися на ті докази (обставини), що не були предметом судового розгляду.

Під час апеляційного провадження прокурори, виконуючи свої повноваження, висловлюють мотивовану позицію щодо законності оскарженого судового рішення в межах вимог, викладених в апеляційній скарзі, а за наявності підстав для прийняття рішення на користь осіб, в інтересах яких апеляція не надійшла, ініціюють прийняття судом відповідного рішення. Виступають з ініціативою повторного дослідження обставин кримінального провадження за умови, що вони досліджені судом першої інстанції неповністю або з порушеннями, а також ставлять питання про дослідження доказів, клопотання про дослідження яких судом першої інстанції відхилені або про які стало відомо після ухвалення судового рішення.

\section{Висновки}

Отже, узагальнюючи діяльність прокурора в апеляційному провадженні, слід зазначити, що прокурор у апеляційному провадженні є досить важливим учасником кримінального процесу і його діяльність здійснюється з метою, щоб: виносились у кожній кримінальній справі законні, обгрунтовані, вмотивовані вироки, ухвали суду; не допустити виконання незаконного, необгрунтованого судового рішення, своєчасно виправити допущені помилки й порушення закону; забезпечити реалізацію гарантованих Конституцією України прав громадян, інтересів держави та суспільства.

\section{Список використаних джерел:}

1. Конституція України від 28.06.1996 № 254к/96-BP. URL: http://zakon5.rada.gov.ua/ laws/show/254/96-в.

2. Кримінальний процесуальний кодекс України : Закон України від 13.04.2012 № 4651-VI. URL: http://zakon5.rada.gov.ua/laws/show/4651-17.

3. Про прокуратуру : Закон України від 14.10.2014 р. № 1697-VII. URL http://zakon4.rada.gov.ua/laws/show/1789-12.

4. Маляренко В.Т., Вернидубов І.В. Прокурор у кримінальному судочинстві. Деякі проблеми та шляхи їх вирішення. Київ : Юрінком Інтер, 2001. C. 208

5. Маринів B.I. Недопустимість повороту до гіршого як гарантія свободи апеляційного оскарження судових рішень у кримінальному провадженні. Юридичний часопис Наиіональної академії внутрішніх справ. 2013. № 2. С. 114-119.

6. Про затвердження Порядку організації діяльності прокурорів і слідчих органів прокуратури у кримінальному провадженні : Наказ Генерального прокурора України від 28.03.2019 р. № 51. URL: http://search.ligazakon.ua/1_doc2.nsf/ link1/RE33334.html.

The article provides a theoretical and regulatory analysis of the prosecutor's involvement in reviewing criminal cases by a court of appeal. The main purpose of the work is to investigate the problematic issues related to the prosecutor's participation in the review of court decisions in criminal proceedings, to formulate and scientifically substantiate the conclusions and proposals aimed at improving the procedure of the prosecutor's participation in the stage of judicial review.

It is established that the possibility of reviewing the legality, validity and motivation of court decisions in appeal proceedings on the appeal of interested persons is considered a constitutional guarantee of justice, which guarantees the right of a person to appeal a court decision by lodging an appeal by the participants of the trial. Among such participants, the prosecutor holds a special place.

It is stated that the stage of the appeal proceedings is a guarantee of securing a lawful, well-founded and fair judgment. At the same time, the review of court decisions by the appellate court provides for the formation of a unified approach to the application of criminal and criminal procedural legislation of Ukraine, which establishes a number of important provisions governing the prosecutor's powers at this stage of criminal proceedings.

It is proved that in case of violation of substantive or procedural law the prosecutor is obliged to respond in a timely manner to unlawful court decisions by filing an appeal with the purpose of fulfilling the human rights function entrusted to him, the content of which is to protect and restore the violated rights of the citizen and human, the interests of the state and human interests, society. The mechanism of exercising this function is that the prosecutor must within the time limits set aside for appealing court decisions that have not come into force, become acquainted with them and the materials of the court proceedings, appeals from other participants of the process, submit written objections to them, timely appeal every unlaw ful judgment and to participate in a criminal case in an appellate court.

Much attention is paid to the regulatory and legal regulation of the prosecutor's participation in the court of appeal, the standardization of the procedure for lodging an appeal by prosecutors of different levels, as well as the departmental control over the process of appealing against illegal court decisions. It is emphasized that in some criminal proceedings only the prosecutor, as a state prosecutor, can appeal against an unjustified decision of the court of first instance due to the absence of the victim in such cases and the defense party is not interested in reviewing this court decision.

Key words: prosecutor, court decision, appeal, appeal proceedings, Prosecutor General. 